\title{
Reducing Environmental Damage Caused by the Collection of Cooking Fuel by Refugees
}

\author{
Maureen LynCH
}

\section{Abstract}

The collection of fuelwood by large numbers of internally displaced people and refugees for the purpose of providing energy for food preparation and cooking can cause environmental devastation and adversely affect the socio-economic balance with local populations. There is no simple solution. Reducing environmental impact, and thus easing societal tensions, requires addressing a complex set of issues including supply of and demand for natural resources, aid agency operations, willingness to utilize refugee knowledge and experience, the effects of forced displacement, poverty, and lack of land. The key to establishing sustainable solutions, whether fuel or non-fuel alternatives, requires being able to identify and understand the interaction between human needs and behaviour and the local environment. This paper explores the scope of the problem and offers case examples, describes efforts taken and alternatives available, presents outcomes of evaluations that have been performed, and outlines lessons learned to be used in future crises.

\section{Résumé}

La collecte de bois de chauffage par un grand nombre de personnes "déplacées internes " et de réfugiés pour préparer la nourriture peut provoquer des destructions écologiques et déséquilibrer les relations socio-économiques avec les populations locales. Cependant il n'existe pas de solution aisée. Pour minimiser l'impact écologique et ainsi apaiser les tensions sociétales, il faudra confronter un ensemble complexe de problèmes, comprenant l'offre et la demande de ressources naturelles, les opérations des agences d'aide, l'acceptation d'utiliser la somme de connaissance et d'expérience des réfugiés, les conséquences des déplacements forcés, de la pauvreté et de la pénurie de terre. Pour arriver à des solutions durables, que ce soit concernant l'utilisation ou non de combustibles, il est impératif de pouvoir identifier et comprendre l'interaction qui existe entre les besoins et les comportements humains d'une part, et l'environnement local d'autre part. Cet article explore l'étendue du problème et propose des exemples concrets, décrit les efforts entrepris et les alternatives possibles, présente les résultats des évaluations qui ont été entreprises et résume les leçons apprises qui pourraient être valables à l'occasion de crises futures.

\section{Introduction}

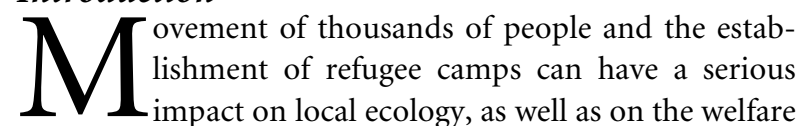
of nearby communities. Refugees collect wood as fuel for cooking and for warmth and fell trees to build shelters. As a result, land surrounding the refugee camps may be stripped of trees and vegetation. News headlines bear titles such as "Firewood Row at Refugee Camp Leads to Killings" and "Officials in Western Ethiopia Accused Sudanese Refugees of Destroying almost 6,000 Hectares (15,000 Acres) of Woodland Every Year."

Refugee agencies by necessity put immediate life-saving humanitarian needs above environmental concerns, but the links between the well-being of human populations and 
a healthy environment are increasingly being taken into consideration. Aid agencies encourage refugee populations to become more closely involved with environmental management and rehabilitation. Most programs address the fuelwood issues through management strategies (i.e., improved stoves and cooking practices), but it has been reported that savings of up to 40 per cent can be attained with improved stoves, and this has not been replicated in field trials. The key to reducing environmental damage caused by demand for cooking energy is identifying and understanding the interaction between human needs and behaviour as well as the local environment.

The number of refugee crises has not dropped and environments will remain at risk. This paper outlines the problem and case examples, efforts taken and alternatives available, outcomes of evaluations that have been performed, and provides a compilation of lessons learned to be used in future crises.

\section{Overview of the Problem}

The United Nations High Commissioner for Refugees (UNHCR) estimates a world population of about fourteen million refugees and between twenty and twenty-five million internally displaced persons. ${ }^{1}$ The large and rapid influx of refugees (both cross-border migrants and internally displaced populations) may have different types of impact on the surrounding environment, varying from the degradation of forests resulting from the collection of firewood to soil erosion, contamination of ground water, or damage to protected areas and national parks, including loss of natural habitat. ${ }^{2}$ There are also impacts on the socio-economic situation at the local level and health effects at the individual level.

It is the demand for energy that often leads to the most serious environmental problems associated with refugee flows. ${ }^{3}$ Existing levels of energy consumption among local communities are often more modest than those of incoming refugees. ${ }^{4}$ This can reflect the longer cooking times of refugee rations compared with fresh food, and sometimes unrestricted access to resources. In the case of firewood, initial per capita consumption of about three $\mathrm{kg} /$ person/ day is typical of refugee camps situation - subject of course to local factors and the cultural background of the refugees themselves. ${ }^{5}$

The intensity of environmental impacts around a refugee camp or settlement is determined by a combination of human and environmental factors including the size of the population, duration of residency and dependence on natural resources, environment-related factors such as the degree of habitat fragility, local levels of biological diversity and climate, and socio-economic factors. ${ }^{6}$
Refugee use of fuel for cooking is generally the single biggest drain, and the biggest determinant of fuel consumption is food supply. ${ }^{7}$ The primary energy source in the majority of refugee situations is wood, or wood-based products such as charcoal. ${ }^{8}$ Other sources, such as coal, kerosene, liquid propane, and electricity, are used less frequently, and usually in urban areas, where the type and scale of impact involved are of a generally less severe nature than those produced in rural areas. The main cooking system used by refugees is an open fire surrounded by three stones on which cooking materials rest. Simple, but inefficient in terms of energy loss, the result, in some instances, has been an excessively high consumption of firewood, with consequent environmental damage. ${ }^{9}$ Refugees may extract standing vegetation to meet their energy needs, implying in some cases the widespread cutting of trees. Even if biomass eventually recovers its original levels, it is possible that biodiversity will be permanently affected. The problem can be more serious where refugees are located in or adjacent to sensitive or protected areas. ${ }^{10}$

Deforestation and land degradation carry with them an indirect economic cost for the local population, as does the reduced availability of fuel derived from nearby forests. The local poor are often affected adversely as refugee demand forces up prices of fuel. Meanwhile some members of local communities may be able to benefit from trade in firewood, charcoal, and other products sold to refugees. ${ }^{11}$ In addition, the host government may experience a loss of revenue from natural resources if refugees deplete reserves. Extraction of firewood, for example, may deprive a government of royalty payments and may also lead directly to more seriously degrading activities such as illegal lumbering or poaching, both of which are likely to result in loss of official revenue.

The environmental impact of a sudden influx of refugees may create hostility between local communities and refugees. Where natural resources such as firewood or water are scarce, people compete for access to these resources. In addition, newly arrived refugees are often unaware of local traditions or laws to protect wildlife resources or sacred sites - a common source of conflict. Behaviour regarding firewood collection and improved stoves is dominated by social customs. While it is often assumed that men have little impact on cooking methods, husbands rank high as a social reference for advice. ${ }^{12}$

There are known linkages between health and long-term exposure to cooking fuel pollutants, particularly among women and children. ${ }^{13}$ Biomass which is not properly dried may cause acute respiratory infections, lung disease, heart disease, destruction of red blood cells, eye disorders, and a variety of infant ailments; coal produces a lot of smoke and a variety of pollutants, including sulphur dioxide and heavy 
metals. Kerosene presents the risk of starting a fire as it is usually stored in containers inside shelters. It is a poison, with special risk for children.

It is important to note that biomass can be burned with no releases other than the products of complete combustion: carbon dioxide and water. This demands that the fuel be dried properly and fully burned in a well-ventilated area. Charcoal use is reported to produce little smoke. ${ }^{14}$ Gas stoves release less than one-fiftieth of the pollution that is emitted by burning firewood, however. ${ }^{15}$ The association between exposure to raw biomass smoke, acute respiratory illness, and the death of malnourished children has received very little attention by humanitarian assistance providers. Improving the efficiency of the stove and efficiency in wood use do not eliminate the negative health effects of exposure to raw biomass smoke. Areas outside camps, where women go to gather firewood, can be dangerous due to the presence of anti-personnel landmines or because of assault to which women are subjected. ${ }^{16}$

\section{Case Examples}

The situation for refugees in Angola, Democratic Republic of Congo, Ethiopia, Kenya, Malawi, and Sierra Leone testifies to the impact collecting cooking fuel has on the environment in Africa. In Benguela Province of Angola, ${ }^{17}$ internally displaced (IDPs) women have to walk very long distances to find suitably wooded areas. Collecting enough wood for a week can take up to one full day away from home. They have to prepare food for the family in advance and to organize supervision for the children they leave behind, and they cannot participate in a food-for-wood activity on that day. Walking long distances from the camp to isolated areas can cause fear of getting lost. They are afraid of assaults and rape that can occur on the way. In order to be protected, they form groups and ask men to accompany them. If they are single and cannot approach husbands for protection, they sometimes have to pay protectors with a share of the collected wood.

Angola is also one of the most heavily mined countries in the world. Mine accidents can occur when women who are not familiar with the area collect water or firewood. Also, local residents impede access by formally prohibiting access to certain areas reserved for residents, or by regulating what type of trees can be cut. They use threats of myths and magic to worry the new settlers by, for instance, telling them that a particular path leading to a wood collection area is frequently used by "the big snake" that allows only resident people to pass and attacks strangers. The results of one appraisal exercise showed that even though women were most concerned with acquiring water and fuelwood, they asked for support for agricultural production more urgently, because yields would permit them to buy fuelwood.

Between the years 1994 and 1996, while the Rwandan refugees from the camps and other individuals plundered the Virunga National Park in the Democratic Republic of Congo (then Zaire), an estimated thirty-six million trees were cut within the park boundary. Another way to view the problem is that some 410 to 770 tons of forest products (mainly wood for fuel) were removed daily. ${ }^{18}$ At the height of the crisis, between 25,000 and 30,000 people took wood from the park each day. Most of this was for firewood for cooking the disaster-relief foods that were distributed in the camps. ${ }^{19}$

In Ethiopia, ${ }^{20}$ shortage of vegetation has had important implications for the refugees. Firewood and charcoal are the primary sources of heat for cooking. Surveys that collected information on wood intake, household energy, camp market, stove utilization, and catering, showed that 75 per cent rely on firewood and use the traditional three-stone cooking system. Five per cent of the population uses charcoal exclusively in a type of stove known as the "girgir." The remaining 20 per cent of families use a combination of firewood and charcoal and possess both a three-stone system and a girgir stove. Overall, women carry 26 per cent of all wood loads while children bring 24 per cent. Men carry slightly fewer loads, 22 per cent, but their overall contribution is actually 8 per cent greater than women's in terms of weight. The mainstay of the refugee diet is wheat grain, most of which is eaten whole after boiling in water (or water with milk) and which takes up to three hours to cook. It is estimated that 20 per cent of the grain is also milled. Other staples include rice, pasta, and soup. Although many food items in the refugee diet cook relatively fast, it is the slowest-cooking dish - whole-wheat grain - which is the one most commonly prepared. In evenings there is widespread non-cooking use of fires, with 72 per cent of families using the fire for heat, 69 per cent for light and 33 per cent for social family gatherings.

Land around refugee camps in Kenya has been stripped clean of trees and vegetation. The average Kenyan spends about 40 per cent of earned income on fuel, 74 per cent of which is used for cooking. ${ }^{21}$ Women spend about five hours a day searching for fuelwood to last for three days. The use of solar cookers and hence less need to collect fuelwood has provided women with more free time which may be used for social betterment such as caring for children or for improvements in agricultural practices. The United Nations estimates that solar cooking will reduce the felling of trees around the camps by 40 per cent, a tremendous benefit for the environment in soil erosion reduction. Further benefits that resulted from the solar cookers in the refugee camps were increased cleanliness and improved nutritional 
content of food as compared to food cooked using traditional methods of cooking.

The implementation of solar cookers in two refugee camps in Kenya has been regarded as a success. Since the introduction of the new model of cooker has taken place only recently and because the costs of the cookers in many cases were heavily subsidized, it remains to be seen whether or not the solar cookers will be affordable. It is estimated that the new model of cooker would cost two to three dollars (U.S.), which may be a relatively large investment for certain Kenyans, especially if a traditional cooking area is still required.

Malawi hosted over one million refugees at one single time period. ${ }^{22}$ The presence of such a proportion in relation to the local population, at the ratio of 1:10 (one refugee to ten Malawians), posed a big strain on an already fragile environment. The high rate of deforestation ensuing from demand for more farmland, firewood, and timber for construction has caused a myriad of environmental and social problems. Nongovernmental organizations and government departments in collaboration with UNHCR made efforts to reduce the rate of environmental degradation in the refugee camps/settlements. They produced fuelwoodsaving stoves and distributed them to the refugees, and planted trees in and around the settlements. Although this had a significant contribution in conserving fuelwood and saving the few remaining surrounding trees and shrubs, the rate of tree felling for various reasons (charcoal burning, firewood selling to generate income) was beyond the limit that the control mechanism could cope with.

In Sierra Leone, fuel is not included in the non-food items refugees receive. They go to the forest to find and collect firewood to sell in order to buy one or two ingredients and to cook. They cut firewood with their hands because they don't have tools. At times they get hurt, attacked, or raped on their way to the forest. Those who cannot go to the forest send their children to panhandle, and those who have lost their children to the war panhandle themselves. Single mothers with infants and lots of children to take care of go to the streets and beg in order to survive. They also go without food most times because they give priority to their husbands and/or children when their food supply gets too low. When new Liberian refugees go out and collect wood, Sierra Leoneans will chase them.

Within Asia, the countries of Afghanistan, Nepal, and the Thailand/Burma border have notable environmental difficulties caused by refugees. As a consequence of more than twenty years of war and uncontrolled resource exploitation, Afghanistan's environment is under serious threat. The area covered by natural forests has decreased from around 6 per cent in 1977 to less than 2 per cent today. ${ }^{23}$ Some such changes also have social impacts such as conversion to inferior cooking fuels (including animal manure) and greater household expenditure on energy for cooking and heating. Nearly all Afghans, with the exception of a small urban wealthy population, depend entirely on firewood for both heating and cooking fuel. The small and ever decreasing amount of wood available in local bazaars will be prohibitively expensive for many, and is predicted to be exhausted by 2005 .

The return of more than one million refugees from Iran and Pakistan has exacerbated existing problems by making the use of construction materials and fuel from natural forests even less sustainable and by adding significantly to urban populations. Return in the coming years can be expected to add to existing environmental pressures.

In Nepal, the major influx of refugees occurred from 1990 to 1993 , and the camps still exist today. In the area where the camps are, more than 70 per cent of the total land area has been cultivated, and the remaining forest resources occupy 10 per cent and 16 per cent of the land area. Deforestation is considered the most serious threat arising from the presence of the refugees, the population influx adding to the existing pressure on the local forest resources, though no formal study on the impacts of refugee firewood gathering has been carried out. ${ }^{24}$ In some cases the land now occupied by the refugee camps had already suffered from previous human interference and was already in degraded or bare condition. To minimize the reduction in forest-cover several reforestation projects have been successfully applied in the Beldangi camps.

On the Thailand/Burma border, where refugees are no longer able to go out of the camps to forage in the forest or earn a cash income and are living in camps too crowded for gardens or livestock, many Karen refugees are now more dependent on NGO assistance. Where refugees are not allowed to cut bamboo or gather firewood, NGOs have had to provide building materials, cooking fuel, and supplementary food. The moves themselves cause insecurity as refugees lose access to their gardens and opportunities to forage, while having to expend more energy in moving and rebuilding. They may be arrested for harvesting Thai bamboo.

The Northern Caucuses have not escaped environmental devastation. In Azerbaijan, forest statistics do not show noticeable deforestation, but there is evidence of it around refugee camps and areas affected by the 1992-1994 war with Armenia over Nagorno Karabakh. ${ }^{25}$ Without other sources of energy, internally displaced people have had to rely on fuelwood. People displaced from Chechnya describe ruined forests and barren and burning fields where homes once stood. ${ }^{26}$ "The ecological situation in Chechnya is cata- 
strophic," said Zalina Abiyev, a 57-year-old refugee who fled Grozny. "We're all afraid to go back because we'll die like flies there, guaranteed." "Not a single refugee camp has sufficient supplies of firewood or coal." Many of the walnut trees and oaks that once lined the main highway leading west from Grozny have been whittled down to stumps by Chechens seeking firewood. ${ }^{27}$

\section{Agency Guidelines}

UNHCR has long dealt with environmental issues in and around refugee camps and settlements. The Office of the Senior Coordinator on Environmental Affairs was established in 1993, and in the following year, the Interim Guidelines on the Environment were prepared. In December 1994, UNHCR's Senior Management Committee established an internal Working Group on the Environment. A geographical information system (GIS) environmental database was initiated in 1994 and includes worldwide geographical locations of refugee camps, numbers of refugees, and main environmental parameters (such as topography, hydrology, vegetation and forest cover, and protected areas) surrounding these camps. There was also the drafting of UNHCR Environmental Guidelines that are built on four basic environmental principles of integration, prevention, cost-effectiveness, and local participation. ${ }^{28}$

Integration of environmental concerns into the Agency's operations has meant incorporation of environmental concerns into sectoral guidelines and manuals, the establishment of UNHCR environmental policies, preparation of a user-friendly environmental sourcebook of ideas for implementing environmental projects, and further promotion of environmentally friendly procurement. Sectoral guidelines include: Forestry Guidelines for Refugee Situations; Domestic Energy Guidelines for Refugee Situations; Livestock Guidelines for Refugee Situations; and Environmental Guidelines for Refugee Agriculture. The UNHCR Handbook for Emergencies recommends inclusion of an environmental specialist in the emergency team, preparation of an Environmental Strategy and Action Plan, establishment of a local environmental task force for regular coordination among major actors concerned, and inclusion of a section on environment in budget submissions.

For field operations, there must be coordination of policy and planning with other United Nations agencies, to ensure coherent environmental activities in the field. It is important to promote the participation of the beneficiaries as well as of the local populations in setting objectives, planning, and implementing activities; this is considered crucial to making environmental measures sustainable. Particular attention has to be given to poor and vulnerable persons, as well as refugee women and refugee children, who suffer disproportionately from refugee-related environmental problems.

\section{Cooking Energy Alternatives to Firewood}

The greatest challenge is to find technologies that are as efficient and non-destructive as possible and yet are adaptable to socio-cultural norms. Alternatives to firewood include briquettes, charcoal, cow dung, diesel and petrol, electricity, fast-growing plants, gas from bio-latrine, gelfuel, grassburning stoves, kerosene, loose residues, liquid propane, natural gas, peat, and solar energy. These systems are briefly described below.

There are several types of burnable briquettes. ${ }^{29}$ The primary limitations of any of them are that large quantities of raw material are needed and supply may fluctuate seasonally. Careful packaging and transportation is needed to avoid crumbling or moisture damage. They need a special stove that provides proper ventilation, and this is not easy to light. Moreover, the production of briquettes is relatively expensive.

Charcoal production often grows into a local economy around refugee camps. However, since the charcoal is sold, many refugees cannot afford to buy it, causing them go out to collect fuelwood anyway. Cow dung is often used where there are few other alternatives for fuel. It is usually formed into cakes or put onto sticks or walls to dry. Its use reduces its function as fertilizer, but provides a fuel mix for meeting energy demand. ${ }^{30}$

Diesel and petrol are normally the short-term fuel choice for electricity generation, being simple to use and readily available worldwide. There are, however, polluting, nonrenewable and normally imported. They also tend to promote a culture of wastefulness, as power output is effectively unlimited given sufficient generator units. It has been suggested that electricity should not be used for cooking due to the amount of waste and energy inefficiency that can occur with its production. Manual electricity can be used as a back up, or even as a principal source. Games may be created for children and adults to participate in which actually produce electricity, pump water, or grind meal in the process.

Fast-growing plants are a fuel alternative with growing popularity. In situations where there are few alternatives, this approach should be considered. ${ }^{31}$ But one fuel with considerable social resistance to its use is gas made from a bio-latrine. ${ }^{32}$ In refugee situations the number of women and children is often disproportionately high and the diet is non-standard, the average waste output per person could be expected to be substantially lower that the standard three litres. Around fifty refugees are required to supply enough gas for about five persons. 
Gelfuel is based on biomass ethanol alcohol, which is produced through the fermentation and distillation of sugar cane, sweet sorghum, or other agricultural crops. ${ }^{33}$ As such, it is 100 per cent organic and can be locally produced in most countries in Africa. Appropriate low-cost, high-efficiency stoves have been developed specifically for the gelfuel, and a gelfuel burner has been designed which can be retrofitted into more than fifteen traditional African cooking stoves.

Grass can be burned and has been shown to have positive results in areas of severe local fuelwood shortage. Grass accessibility depends very much on its seasonal availability and most refugees that have experimented with grass-burning programs have expressed a reluctance to store grass for future use. The use of kerosene is an option that is generally not liked because it is dangerous and expensive. ${ }^{34}$ The fuel must normally be imported, which generates a foreign exchange burden and dependence on a non-renewable fuel. The main drawback with kerosene supply is the risk of sale of the fuel and the stoves, creating a grey market for kerosene and the cooking hardware that might spread far from the refugee-hosting area.

Loose waste/agricultural residues include sawdust, sugar-cane bagasse, cassava stems, coffee husks, maize cobs, coconut shells, sunflower husks, groundnut shells, rice husks, cottonseed residues, and grasses. ${ }^{35}$ These are inferior to firewood and charcoal due to higher ash content that inhibits ventilation during combustion, and to lower density and calorific content with high transport costs per unit of energy. This system requires close tending.

Liquid propane gas or butane under pressure is an efficient, low-emission energy source. ${ }^{36}$ Its thermal efficiency for cooking is very high due to the quality of appliances available. It has the same range of drawbacks as kerosene and is considerably more costly. Scientists have suggested switching to small stoves that burn natural gas, which is plentiful and clean. ${ }^{37}$

Peat can be cut manually from swampy areas and then dried before use. ${ }^{38}$ Mechanized extraction is viable if the area is first drained and dried, but as this can take two years it is not necessarily suitable for refugee situations and is also likely to result in irreversible environmental damage, whereas cutting from undrained swamps is more likely to be compensated for by natural regeneration. The use of peat has high smoke emission, varies in quality, must be cut and used in a specific way, and is found only in localized sites under suitable moisture conditions.

Although solar cooking requires no fuel at all, this method does not replace, but only complements, other forms of cooking (and thus still requires traditional sources of fuel). Solar-powered ovens require no fuel at all. Durable solar cookers are expensive and the components are likely to be sold by those who receive them. There is little hard data about the real environmental savings involved in solar-cooking projects. One study found that "normal" solar cooker users saved 27 per cent of their firewood. The same study reported that "maximum" solar users reduced their firewood usage by 68 per cent. The use of solar cookers whenever the conditions are right has reduced the demand for firewood. Solar cookers are safe and there are no dangers of fire getting out of control. Solar cooking is clean and hygienic. Solar-cooked food retains its nutrients. ${ }^{39}$ But solar cooking needs a high number of days of isolation, a high degree of remoteness, scarcity of firewood and inability (or great difficulty) of refugees to obtain alternative fuel, and some likelihood of acceptance of new ideas, at least by part of the refugee population. Frequent complaints of refugees include the cooker's slowness, its uselessness on cloudy days, and the lack of availability of beans or maize flour.

\section{Non-fuel Solutions}

There are also a number of non-fuel solutions that can be used to reduce energy usage in cooking. The simplest way of reducing the impact of refugees (though it is often not politically possible) is to set up a larger number of smaller camps, rather than a tiny number of large ones. The benefit of this approach is that fuelwood collection is automatically spread over a larger area. Other solutions include using fuel-efficient stoves and adjustments to food preparation and cooking methods.

One common alternative is fuel-efficient stoves. ${ }^{40}$ Fuelsaving systems rely on the two principles of (a) enclosing and insulating the fire and (b) controlling the airflow. Improved stoves can be either user-built or manufactured. Types of fuel-efficient stoves include mudstoves, fabricated stoves, and haybasket cookers.

Grinding reduces cooking time by many hours and energy consumption by up to 80 per cent. Household-level grinding is not as efficient as mechanical milling, but results in less destruction of nutrients by heat. It requires slightly more preparation time, and these foods must be brought into the camp in the first place. Cutting food into smaller pieces makes it cook faster so that fuel savings of 20 to 30 per cent can be realized. ${ }^{41}$

In addition, the cooking time of hard grains and beans can be greatly reduced by soaking them in water for five to eight hours prior to cooking, resulting in energy savings of as much as 40 per cent. This is not a simple practice to introduce because people are likely to complain of a difference in flavour. Although such differences are rarely confirmed in field tests, the belief persists. 42 One downside of presoaked food is that it normally loses colour and texture. 
The demand for energy can be reduced by using different pots. Metal pots should be used for boiling and preparing fast-cooking foods such as rice and potatoes. ${ }^{43}$ Clay pots are ideal for dishes requiring extensive simmering such as maize and beans. Lids may be distributed and are not always the right size. ${ }^{44} \mathrm{~A}$ tight-fitting lid can save 20 per cent of fuel. Pressure cookers, if available, are even more efficient. Simmering cooks food just as quickly as rapid boiling, while ensuring that more of the nutritional value is retained. Once food in a covered pot has been brought to the boil, it is often not necessary to add more fuel to the fire because the retained heat of the fireplace, stove, and pot is transferred to the food. Fuel can even be removed once boiling point has been reached, resulting in substantial energy savings of up to 50 per cent. ${ }^{45}$

Once the cooking is complete the fire can be deliberately put out rather than allowed to burn out naturally. This can save 15 to 20 per cent of fuel, but is only likely to be accepted if matches are available for relighting later on. ${ }^{46}$ While one pot is on the fire a second can be placed on top to start getting warm. This second pot also acts as a lid. Fuel savings of 30 to 40 per cent can be achieved by proper shielding of fireplaces; this can be done using readily available material such as rocks, mud, or pieces of firewood in the process of drying. ${ }^{47}$

The option of using multi-family cooking will depend to a great degree on the social traditions of the refugees themselves, but it is certainly to be encouraged from an environmental point of view. There is an increase in the potential for disease transmission associated with the adoption of a multi-family cooking approach due to the generally high density of living arrangements prevailing in refugee situations.

Another important consideration is fuelwood delivery. While trucking in contracted fuelwood is expensive and often dangerous for the contractor, since s/he must often drive valuable materials through violence-prone areas, fuel delivery is a method that has been used to reduce the incidence of women being raped as they go to collect fuel. Most of the programs that have been implemented so far have shown marked success in lowering the numbers of reported rapes in refugee camps, but they have hardly been sufficient. A second benefit of trucking fuel is that it can ease devastation in the immediate area.

\section{Evaluation of Energy-Saving Options}

In the mid-1990s, UNHCR facilitated the study of several energy-saving cooking options. ${ }^{48}$ The traditional open-fire system was used as the benchmark to which solar cookers and grass-burning stoves were compared, along with other strategies such as wood stoves and energy-saving cooking practices. They were evaluated for environmental impact. Field visits took place in Uganda, Tanzania, and Ethiopia from July to October 1998.

Overall, in a study of grass-burning stoves in Uganda, it was found that the promotion of grass stoves was not a cost-effective measure. It did not achieve the expected social or environmental benefits. Most of the manufactured stoves remained unused due to the lack of acceptance, which was attributed to cultural practices and economic constraints. In addition, it was not clear that cutting and burning grass was preferable, in terms of environmental impact. In Tanzania, there was relative success of the grassburning stove program. Some problems emerged with sourcing grass, including the local tradition of grass burning, the seasonal availability of grass, and reluctance on the part of the refugees to store grass. The fact that stove distribution had been almost entirely donor dependent might affect the overall sustainability of this initiative unless significant efforts are made to coordinate this with the work of other agencies in the area.

The experience with solar cookers in Ethiopia revealed that, while enabling refugee families to substitute some of their fuelwood or charcoal consumption, adoption of the "Cookit" solar cooker encountered some barriers related to its slow cooking speed and inability to meet the requirements of above-average family sizes. While 60 to 80 per cent of recipients appeared to make some use of their cooker immediately after distribution, it seemed best suited to smaller families who could not afford to buy fuelwood. The fact that the plastic bag (inside which the pot sits) had a short lifespan led to a limited application of the cooker. As a result, the Cookit ended up being used only to prepare hot drinks and wheat grain for two-thirds of the year (when solar conditions were not considered optimal), and other foods for the remainder of the year.

\section{Lessons Learned and Conclusion}

There is no blueprint strategy or course of action for eliminating the environmental damage caused by the collection of fuel by refugees, but there are a number of underlying principles that can be utilized to reduce it. Advance preparation, involving the refugees and being ever cognizant of cultural and social norms, choosing the right cooking techniques to save energy, promoting the use of other energy-saving solutions, and collection of data all contribute to reducing the impact of fuelwood collection.

Before new crises arise, desk studies can be undertaken on areas where population movements are likely to occur, so that a basic understanding is developed before the emergency develops. Full use should be made of databases for countries that are likely to be involved in refugee crises, in 
due course. Such files should include information about areas of ample fuelwood resources (if any), border areas of each country most unsuitable for the establishment of refugee camps, and those that ought to be avoided at all costs.

Refugees possess a great deal of knowledge about natural resources, agriculture, and food preparation. They must be a key part in the decision-making processes at all phases. An interactive approach to household energy use, involving refugee participation in reducing consumption, is essential to any sustainable program. In addition, effort should be made to include women in resource management. However, it is important that information not be filtered solely through the elites, who may have reason to misrepresent the facts for political purposes. ${ }^{49}$ The sustainability of any efforts will be limited if the ownership question is not resolved. Camp and local populations must be given equal treatment.

There is still need for better pre-emptive site planning, establishing inter-agency coordination from the start, and promoting better cooking techniques to reduce demand for fuelwood. ${ }^{50}$ There should be camp-by-camp consideration of supply, demand, and protection of natural resources. Where natural resources are abundant, the promotion of tree planting and fuel-efficient stoves runs into serious constraints. Where natural resources around a camp are already degraded, the focus of environmental programs should be quite different. Guided cutting in carefully identified source areas can help meet domestic demand in an environmentally sensitive manner. Cultural, social, economic, and environmental aspects must all be taken into account. Tree and product rights must be defined. Priority should be given to those fuel-saving options that are most positive for health and nutrition, and which reduce rather than increase the burden of labour.

More realistic planning horizons should be used. Refugee camps have lifetimes spanning years rather than months. Every effort must be made to implement a fuel supply program which provides fuelwood cut in a sustainable manner, and includes controls over unauthorized harvesting of sources as well as economic and educational programs designed to reduce fuelwood consumption. Taking into account the local natural resource situation and refugee familiarity with alternatives, it is best to use what is available locally and is the most sustainable and economically viable. Homestead planting and agro-forestry are key areas that may be worthy of more support.

Collection of baseline environmental data should be undertaken from the earliest possible moment, ${ }^{51}$ and should be repeated at regular intervals, on: consumption, rates of tree cutting, types of cooking systems and their efficiencies, and the effect of diet on energy demand. Energy supply and demand assessments should be instituted. Much cooking fuel is consumed by small-scale businesses, but these are rarely considered in fuel-saving initiatives or assessment. In addition, camp-based institutions with cooking energy demands include schools, hospitals, feeding centres, and orphanages, should be evaluated as well. To the degree possible, standard units should be employed to facilitate data storage and comparison.

Promotion of energy-efficient stoves must be carried out in conjunction with other environmental protection/management activities. And all possible adaptations to cooking systems should be widely explored and appreciated. ${ }^{52}$ In addition to providing fuel cost-efficient foods in relief, and milling facilities can be included as a relief item. ${ }^{53}$ Promotion of familiar fuels and cooking systems should take priority over unfamiliar ones. Introducing simple technology does not mean that simple training is sufficient. If possible, clear incentives (economic or other) can be used to promote efficient use of firewood and stoves should be manufactured on site and by the refugees themselves.

The matter of collection and use of cooking fuel by displaced populations is not only about environmental damage and sustainable resource management. It is a complex issue related to various mechanisms developed to cope with the effects of forced displacement, poverty, and lack of land. There are no simple solutions, but there are opportunities to utilize the past experiences and lessons learned to reduce the environmental impact of securing cooking fuel. The keys are identifying and understanding the interaction between people needs and behaviour as they relate to a new, and sometimes unfamiliar, local environment.

\section{Notes}

1. "Basic Facts," online: UNHCR < http://www.unhcr.ch/cgibin/texis/vtx/home/+cwwB meLqZw_wwwwM wwwwwwwmFqtFEIfgIhFqoUfIfRZ2ItFqtxw5oq5zFqtFEIfg IAFqoUfIfR Z2IDzmxwwwwwww1FqtFEIfgI/opendoc.htm\#World\%20Refugee\%20O verview $>$ (date accessed: 30 July 2002).

2. "Refugees and the Environment," online: UNHCR $<$ http://www.unhcr/ch/cgi-bin/texis/vtx/home/+TwwBems e-dbdwwwwn wwwwwwwhFqA72...> (date accessed: 5 May 2002).

3. United Nations High Commissioner for Refugees (UNHCR), Environmental Guidelines: Domestic Energy in Refugee Situations. (Geneva: UNHCR, 1998).

4. Ibid., 7.

5. Ibid., 7.

6. "Guidelines for Environmental Management," online: UNHCR <http://www.unhcr.ch/cgi-bin/texis/vtx/home/ +OwwBmezp_w_wwwwn wwwwwwwhFqA7...> (date accessed: 22 May 2002). 
7. UNHCR, p. 35 .

8. Ibid., 3 .

9. "Evaluation of Energy-Saving Options for Refugees," online: UNHCR < http://www.unhcr.ch/cgi-bin/texis/vtx/ home/ +qwwBmeVP8w_wwwwq wwwwwwwhFqA7...> (date accessed: 22 May 2002).

10. UNHCR, p. 13.

11. Ibid., 6 .

12. R6849- Adoption Barriers for Efficient Domestic Energy in Refugee Sites, online: <http://www.estu.com/dfid-kar-energy/ html/r6849.html $>$ (date accessed: 13 May 2002).

13. UNHCR, 3 .

14. Ibid., 4 .

15. Ibid., 4.

16. "Food Aid and Gender in Emergencies" - no further information.

17. Corinna Kreidler, "The Provision of Household Energy: Coping Mechanisms of Internally Displaced People in Benguela Province, Angola," Boiling Point 46 (Spring 2001).

18. "Mountain Gorilla Protection: A Geomatics Approach," 1994, online: <http://www.informatics.org/gorilla/dimaps.html> (date accessed: 13 May 2002).

19. UNHCR, Refugee Operations and Environmental Management: Key Principles for Decision-making (Geneva: UNHCR, 2000).

20. Matthew Owen, Baseline Energy Survey Aisha Refugee Camp Ethopia (Geneva: UNHCR).

21. Jill M. Maccaferri, reviews of "Breaking through at Kenyan Refugees Camps," by Solar Cookers International, and "Cookstoves for the Developing World," by Daniel M. Kammen, Scientific American 273, no. 1 (July 1995):72-75, online: <http://www.cobly.edu/personal/t/thtieten/sol-ken.html> (date accessed: 13 May 2002).

22. Robert Kafakoma, "Environmental Rehabilitation of the Refugee Impacted Areas: Malawi," Evangelical Lutheran Development Programme/Lutheran World Service (1996).

23. "Field Projects Past and Present: Environmental Protection and Management to Benefit Returning Refugees, Afghanistan," online: UNHCR <http://www.unhcr.ch/cgi-bin/ texis/vtx/home/+ZwwBmeCF_w_wwwwn wwwwwwwh FqA72ZR0gRfZNtFqrpGdBnqBAFqA72ZR0gRfZNcFq3v $>$.

24. "Fertility, Firewood and Water Collection in Nepal," online: <http://worldbank.org/research/peg/wps19/indexp4.htm> (date accessed: 17 May 2002).

25. P. Shyamsundar, K. Hamilton, L. Segnestam, M. Sarraf, and S. Fankhause, "Country Assistance Strategies and the Environment," Environment Department, World Bank, March 2001.

26. "Home Is a Tent or Railroad Car," Dispatches from Chechnya, no. 3, 15 October 2000, online: <http://www.idee.org/lreport3.html $>$ (date accessed: 13 May 2002).

27. INFOTERRA: Russian Environmental Digest (REDfiles), 6 March 2000, online: $<$ http://www.cedar.at/mailarchives/infoterra/2000/msg01518.html $>$.

28. "Progress Report on the Guidelines on Refugees and the Environment," online: UNHCR <http://www.unchr.ch/cgi-
bin/texis/vtx/home/=kwwBmeXUZ69wwwwpwww wwwwhFqhO...> (date accessed: 22 May 2002).

29. UNHCR, p. 15

30. Ibid., 17.

31. Soumalia Dan Baria and Pierre Montagne, "Household Energy Strategy: One Element of the Overall Forestry Strategy: Niger," The World Bank Group Online, online: <http:// www.worldbank.org/afr/afr_for/interim/sniger.htm > (date accessed: 17 May 2002).

32. Ibid., 19.

33. "Exploring Alternatives to Africa's Growing Energy Needs," online: DevNews, 19 December 2001, <http://www.world bank.org/developmentnews/stories/html/121901a.htm> (date accessed: 17 May 2002).

34. UNHCR, p. 20.

35. Ibid., 14.

36. Ibid., 20.

37. Joseph B. Verrengia, "Engineers Look at How to Help Refugees," online: newsobserver.com, 22 May 2002, <http://news observer.com/business/v-print/story/1400102p-1434382c.h tml $>$ (date accessed: 22 May 2002).

38. UNHCR, 18.

39. UNHCR, Office of the Senior Coordinator on Environmental Affairs, The Experience of UNHCR and its Partners with Solar Cooker in Refugees Camps (Prepared by Elizabeth Umlas) (Geneva: UNHCR, 1996).

40. UNHCR, 19.

41. Ibid., 33 .

42. Ibid., 33 .

43. Ibid., 34 .

44. Ibid., 34.

45. Ibid., 33 .

46. Ibid., 33 .

47. Ibid., 33.

48. UNHCR, Evaluation of Energy-Saving Option for Refugees: Grass Burning Stove - Uganda, Grass Burning Stove-Tanzania, Solar Cooker - Ethiopia: Summary Report (Geneva: UNHCR, 1998).

49. DANIDA, "Assessment of Performance: Taking Account of the Views of Beneficiaries and Mitigating the Impact on Host Communities," The International Response to Conflict and Genocide: Lessons from the Rwanda Experience, online: $<$ www.um.dk/danida/evalueringsrapporter/1997_rwanda/b 3/c7.asp > (date accessed: 13 May 2002).

50. GEO-2000 Chapter 2: "The State of the Environment - Africa," online: <http://www.unep.org/geo2000/english/ 0053.htm> (date accessed: 14 May 2002).

51. UNHCR, 2000.

52. UNHCR, Engineering and Environmental Services Section, Refugee Operations and Environmental Management: Selected Lessons Learned (Geneva: UNHCR, 1998).

53. REDI Renewable Energy Development Institute, REDI Activities, online: <http://home.worldcom.ch/redi/experne.html> (date accessed: 13 May 2002). 
Dr. Maureen Lynch is Director of Research for Refugees International, a Washington-based advocacy organization. She previously worked for the UN High Commissioner for Refugees and has undertaken fieldwork for Refugees International in Ingushetia, Azerbaijan, Georgia, Malawi, Zimbabwe, Kosovo, Cambodia, Lebanon, and the Occupied Palestinian Territories.

(C) Maureen Lynch, 2002. This open-access work is licensed under a Creative Commons Attribution-NonCommercial 4.0 International License, which permits use, reproduction and distribution in any medium for non-commercial purposes, provided the original author(s) are credited and the original publication in Refuge: Canada's Journal on Refugees is cited. 